\title{
Analisa Potensi Geografis Timur Tengah Menjadi Kekuatan Teritori Melalui Komik Digital Berlandaskan Paradigma Pedagogi Reflektif
}

\author{
Brigida Intan Printina \\ Program Studi Pendidikan Sejarah, Fakultas Keguruan dan Ilmu Pendidikan, \\ Universitas Sanata Dharma
}

\begin{abstract}
Abstrak
Analisa Potensi Geografis Timur Tengah Menjadi Kekuatan Teritori Melalui Komik Digital Berlandaskan Paradigma Pedagogi Reflektif telah menjawab tantangan era Revolusi Industri 4.0 menjadi peluang. Tujuan penelitian ini ialah 1)menganalisis potensi geografis Timur Tengah menjadi kekuatan teritori ; 2)menguraikan komik digital berlandaskan paradigma pedagogi reflektif. Metode yang digunakan adalah penelitian kualitatif yang menggambarkan tentang kegiatan atau informasi tentang kondisi kelas yang sedang berlangsung. Data penelitian dikumpulkan melalui observasi dengan teknik cuplikan yang dikenal dengan purposive sampling. Sampel yang digunakan adalah salah satu informan untuk mendapatkan informasi mengenai media yang tepat. Hasil penelitian menunjukan bahwa 1) Banyak pelopor nasionalisme Arab yang memiliki misi menyelamatkan bangsanya terbebas dari tradisi yang terlalu konservatif untuk tetap memajukan bangsa serta terbebas dari penetrasi asing diantaranya Sultan Abdul Hamid II(Turki), Al-Tahtawi (Mesir), Muhammad Rashid Rida (Syria), Mustafa Kemal Ataturkh (Turki), Gammal Abdul Nasser (Mesir). Selain gagasan para nasionalis wilayah lain yang merasakan pengaruh asing yang kuat langsung bereaksi dengan membuat ketetapan netralitas dengan tidak memihak blok manapun yang memiliki kepentingan. Namun, ada pengecualian untuk Arab Saudi dimana AS tetap bekerjasama dalam bidang ekonomi dan terbukti dengan adanya perusahaan asing ARAMCO (Arabia American Company Oil) dan ini dirasa lebih menguntukan dari pada menempatkan pangkalan militer asing.; 2) Frekuensi mahasiswa yang menguraikan analisa potensi geografis Timur Tengah menjadi kekuatan teritori melalui komik digital berlandaskan paradigma pedagogi reflektif ialah sebesar 30\% atau sekitar 15 dari jumlah keseleuruhan mahasiswa 50, sedangkan topik lain (tokoh, konflik ideologi, konflik kepentingan barat, konflik perbatasan) mendapatkan porsi rata-rata seitar 10-20\%.
\end{abstract}

Kata Kunci: komik digital, Timur Tengah, Pedagogi

\section{Pendahuluan}

Perkembangan negara-negara di

Timur Tengah tidak dapat lepas dari perhatian dunia. Kawasan ini memiliki arti strategi yang besar karena letak geografisnya pada titik pertemuan tiga benua dan kekayaan minyaknya maupun ketergantungan negara-negara Barat dan Jepang pada kekayaan minyak itu. Perkembangan negara Timur Tengah menjadi lebih penting dan menarik perhatian dunia karena terjadi di suatu kawasan yang di masa kini dan mendatang menjadi pusat perimbangan kekuatan global Timur dan Barat. Sejak dahulu, Timur Tengah mempunyai arti strategis yang menjadi incaran negara-negara besar. Hal ini dikarenakan letaknya pada pertemuan Eropa, Asia dan Afrika, kawasan Timur Tengah menguasai jalan-jalan masuk ketiga benua itu. Timur Tengah berbatasan dengan Laut Merah, Laut Tengah, Laut Hitam, Laut Kaspi, Teluk Parsi dan Samudera Hindia. Di kawasan Timur Tengah juga terdapat jalur- 
jalur air yang strategis seperti Selat Bosporus, Selat Dardanella, Terusan Suez, Selat Bab el Mandeb dan Selat Hormuz. Dengan demikian, baik melalui daratan maupun perairan kawasan ini memandang ke banyak penjuru, bahkan keunikan geostrateginya diakui oleh negara-negara besar di dunia. Artikel ini berfokus pada potensi geografis Timur Tengah menjadi kekuatan teritori. Tidak semua orang memandang bahwa Timur Tengah memiliki potensi karena adanya konflik memudarkan pandangan dunia terhadap kekuatan peradaban yang dulu pernah ada.

Para mahasiswa dalam satu mata kuliah terkait konsep tersebut (Sejarah Asia Barat Modern) menyajikan analisa dalam bentuk yang berbeda sehingga semua kalangan mampu memaknai pesan di dalamnya melalui media visual yaitu komik digital. Hal ini merupakan peluang besar bagi pendidik sejarah untuk tanggap situasi generasi dan menjadikan hal tersebut sebagai bahan ilmiah untuk menunjang ilmu pengetahun khususnya pendidikan sejarah.

Selain itu dalam buku "21st Century Skill, Learning for life in Our Times" juga membahas soal Communication and Collaboration yang menyinggung soal kepedulian sosial. Setiap orang memiiki keterampilan daam bekomunikasi dan bekerjasama dengan orang lain. Persoalan yang kompleks menuntut kemampuan komunikasi dan kerjasamaa dengan berbagai pihak sehingga persoalan tersebut secara luas dan mendalam dapat dipecahkan secara tuntas. Orang egois dan tidak mampu berkomunikasi secara interpersonal akan sulit menangani persoalan yang kompleks dalam kehidupan sekarang. Kehidupan yang menuntut sesuatu serba sistematis dan cepat, rentan memicu sikap apatis dan pro individualis. Mahasiswa sebagai calon pendidik dituntut kreatif dalam mengkolaborasikan materi, metode dan media.

Hal ini selaras dengan konsep paradigma pedagogi reflektif yang terwujud dalam 3 unsur yang ada pada tujuan pembelajaran. Ketiga unsur tersebut adalah Competence, Conscience, dan Compassion. Competence merupakan kemampuan secara kognitif atau intelektual, Conscience ialah kemampuan afektif dalam menentukkan pilihan-pilihan yang dapat dipertanggungjawabkan secara moral, sedangkan Compassion adalah kemampuan dalam psikomotorik yang berupa tindakan konkret maupun batin disertai sikap bela rasa bagi sesama (Subagya, 2010: 23-24).

Selain harus berhadapan dengan transformasi zaman, manusia juga harus memiliki nilai humanis supaya manusia dapat menghadapi kehidupan yang selaras dengan sesamanya juga di mata Tuhan. Prinsip ini dapat kita pegang untuk menghadapi era Revolusi Industri 4.0. Meski dengan segala perkembangan teknologi manusia diharapkan tetap peduli dengan sesama dan memberi karakter seperti yang 
dikembangkan Santo Ignatius Loyola. Dengan demikian, pantaslah paradigma pedagogi reflektif menjadi sarana yang tepat dalam mengembangkan pribadi yang peduli dengan transformasi media saat ini. Pendidikan di perguruan tinggi menekankan agar mahasiswa tanggap akan segala bentuk tantangan yang kompleks dengan kuat. Ada segi intelektual, sosial, spiritulal, moral, sikap, fisik, estetik, emosi, semua perlu dikembangkan. Di dalam pendidikan itu terdapat daya kritis, inovatif, kepedulian, kejujuran, moralitas yang tinggi, termasuk keterampilan membangun jaringan dengan komputer atau teknologi.

Maka peran dosen menjadi tepat jika mampu mengasah kepedulian sosial mahasiswa. Mereka diharapkan menyadari kegunaan suport sistem untuk meningkatkan kesuksesan belajar. Mahasiswa diajak untuk mulai menyadari bahwa mereka dikondisikan sebagai calon guru sejarah yang inovatif. Kecenderungan minat dan motivasi membaca serta memahami bacaan sekarang sangat kurang.

Maka guru sejarah masa mendatang dapat selektif dan professional dalam menggunakan media pembelajaran agar pembelajaran sejarah lebih menarik dan bermakna. Paradigma pedagogi reflektif yang diterapkan memberi makna cara berpikir dan bertindak yang menyaturagakan nilai kemanusiaan ke setiap materi dalam proses pembelajaran.

\section{Tinjauan Pustaka}

A. Potensi Geografis

Menurut Suharyono dan Moch. Amien (1994: 26-34) Geografi memiliki konsep esensial, diantaranya: 1) konsep lokasi yang berkaitan dengan keadaan sekitar yang dapat memberi arti sangat menguntungkan ataupun merugikan, misal perbedaan daerah yang memiliki SDA strategis wilayahnya subur dan dekat dengan aliran sungai di wilayah Timur Tengah, 2) konsep jarak yang memiliki arti penting bagi kehidupan sosial dan ekonomi misal tingkat kebudayaan dan kehidupan sosial masyarakat di wilayah gurun dengan di wilayah pantai di Timur Tengah.

Beberapa wilayah di Timur Tengah memiliki potensi. Hal ini sejalan dengan kajian Arnold Toybe bahwa hanya karena adanya tantangan dan jawaban terhadap tantangan itu, maka kebudayaan bangsa akan maju. Teori kebudayaan tersebut dibuktikan dimana bangsa Sumeria berhasil menjawab tantangan alam, yaitu mengubah lembah Sungai Eufrat dan Tigris dari rawa dan hutan (bukan daerah strategis dan subur) menjadi daerah pertanian yang subur. Secara politis dan kultural, Timur Tengah dapat dibagi ke dalam dua wilayah utama: Sabuk Utara dan Inti Arab.

Wilayah Sabuk Utara berbatasan langsung dengan Rusia, dan mayoritas etniknya ialah non-Arab. Kehadiran Rusia di utara perbatasan menciptakan ikatan yang tidak tampak, sehingga ada berjuta-juta 
orang memiliki dua pilihan keyakinan untuk memisahkan atau melindungi diri dari budaya Arab. Maka dapat terlihat wajah politiknya sekarang jika Turki, Iran dan Afghanistan berbeda dalam banyak hal. Bila dikaji dari sisi pertahanan yang tidak merata, mata rantai terkuat ialah Turki sedangkan yang terlemah ialah Iran (Asgar Bixby, 1992: xxii).

\section{B. Timur Tengah}

Timur Tengah merupakan sebutan orang Inggris untuk wilayah Asia Barat Daya, wilayah Eropa Tenggara yang pada masa lalu berada di bawah kontrol Turki. Timur Tengah meliputi semua negara yang terletak di sebelah selatan Uni Soviet dan di sebelah barat Pakistan, hingga Mesir di Benua Afrika. Sebelum pemakaian Timur Tengah, sebutan yang lebih umum adalah Timur Dekat (Asgar Bixby, 1992: xxii).

Kirdi Dipoyudo juga menguatkan arti penting Timur Tengah yang telah muncul semenjak Perang Dunia II, digunakan oleh orang-orang Inggris dan Amerika untuk menyebutkan kawasan yang sebagian besar terletak di Asia Barat Daya dan Afrika Timur Laut dan oleh sebab itu dapat dibatasi sebagai jembatan antara Eropa, Asia dan Afrika. Istilah Timur Tengah berasal dari perluasan wilayah komando militer Inggris, yang mula-mula mencakup negara-negara di sebelah timur Terusa Suez, sebagai persiapan perang.

Dalam perang itu, istilah Timur Tengah menjadi lazim dan hampir menggantikan istilah-istilah yang lebih umum seperti "Near East" dan "Levant" (Kirdi Dipoyudo, 1981: 4). Menurut R.H Davidson, Timur Tengah meliputi negaranegara diantaranya: Turki, Iran, Irak, Suriah, libanon, Siprus, Israel, Yordania, Arab Saudi, Yaman Utara, Yaman Selatan, Oman, Uni Emirat Arab, Qatar, Bahrain, Kuwait, Sudan, Simalia, Mesir dan Libia. Kemudian berdasarkan pertimbangan kebudayaan dan politik wilayah Tunisia, Aljazair, dan Maroko ialah termasuk kawasan Timur Tengah. Begitu pula Mauritania dan Djibouti yang masing-masing pada tahun 1973 dan 1977 diterima sebagai anggota Liga Arab.

\section{Kekuatan Teritori}

Kekuatan teritori bergantung pada hak kedaulatan territorial. Ilmuwan politik dunia misalnya David Miller (2012: 252268) menguraikan hak kedaulatan teritori teridiri atas tiga unsure, yaitu kedaulatan hukum, ekonomi, dan perbatasan. Anna Stilz (2011: 572-607) menguatkan bahwa hak kedaulautan teritori sebuah negara terdiri dari lima pilar, yaitu kedaulatan politik, budaya, ekonomi, perbatasan dan hukum. Maka dapat dikatakan bahwa kekuatan teritori ada pada suatu negara yang diakui baik secara de facto maupun de jure dan terbebas dari segala bentuk penetrasi asing.

\section{Komik Digital}

Secara sederhana, digital comics atau komik digital memiliki ciri khasnya, khusus untuk digital comics yang berbasis internet (online), sangat terkait dengan 
kecepatan akses dan bandwith, sehingga perlu mempertimbangkan ukuran dan format gambar dalam komik digital yang dibuat. Digital convergence adalah pengembangan digital comics yang ditautkan pada media berbasis digital lainnya, seperti game, animasi, film, mobile content, dan sebagainya (Hafiz Ahmad, 2009). Konteks ini, komik tidak hanya menampilkan alur cerita saja, tetapi dapat disisipkan game, animasi, film, atau aplikasi lain yang mempermudah pembaca dalam mengikuti dan menikmati cerita yang disajikan. Penyimpanan digital comics dapat dilakukan online / menggunakan gadget.

Aplikasi komik digital yang digunakan ialah Komik Toondoo. Komik Toondoo merupakan media pembelajaran berbasis online dengan website www.toondoo.com. Pada website itu, pengguna dapat membuat dan menyusun materi pembelajaran dalam bentuk komik, mengambil atau membuat tokoh kartun yang sudah tersedia atau membuat tokoh karakter sendiri (dalam www.toondoo.com).

\section{E. Paradigma Pedagogi Reflektif}

Paradigma Pedagogi Reflektif adalah suatu pedagogi bukan hanya sekedar metode pembelajaran. Suatu pedagogi, berarti merupakan suatu pendekatan, suatu cara pengajar mendampingi peserta didik sehingga peserta didik menjadi pribadi yang utuh (Paul Suparno, 2015: 18). Tujuan dari pembelajaran PPR terwujud dalam 3 unsur yang ada pada tujuan pembelajaran. Ketiga unsur tersebut adalah Competence, Conscience, dan Compassion.

Competence merupakan kemampuan secara kognitif atau intelektual, Conscience ialah kemampuan afektif dalam menentukkan pilihan-pilihan yang dapat dipertanggungjawabkan secara moral, sedangkan Compassion adalah kemampuan dalam psikomotorik yang berupa tindakan konkret maupun batin disertai sikap bela rasa bagi sesame (Subagya, 2010: 23-24).

\section{Metode Penelitian}

Penelitian ini dilakukan di R. II/K-34 Kampus I Universitas Sanata Dharma Yogyakarta. Penelitian dilakukan pada perkuliahan Sejarah Gereja. Subyek penelitian adalah mahasiswa semester III Program Studi Pendidikan Sejarah FKIP USD Tahun ajaran 2018/2019. Obyek penelitian yaitu komik digital untuk menganalisis potensi geografis Timur Tengah.

Penelitian ini menggunakan jenis Penelitian ini merupakan penelitian kualitatif deskriptif. Teknik Pengumpulan data salah satunya Observasi yaitu menggali data dari sumber data yang berupa peristiwa, aktivitas, perilkau, tempat atau lokasi, dan benda serta rekaman gambar. (Sutopo, 2006: 67-69) Penelitian ini menggunakan teknik cuplikan yang dikenal dengan purposive sampling (Sutopo, 2006: 64). Peneliti memilih salah satu informan dianggap dapat menjawab informasi yang berkaitan dengan pemanfaatan media 
pembelajaran komik digital. Validitas data dalam penelitian ini menggunakan trianggulasi sumber/data dan metode.

\section{Hasil Dan Pembahasan}

\section{A. Potensi Geografis Bekas Peradaban Mesir}

Lembah sungai Nil menjadi ciri khas geografis strategis bangsa Mesir dan diperebutkan berbagai wilayah tidak hanya wilayah di sekitarnya namun juga bangsa Eropa pada abad ke 20. Peradaban Mesir yang maju telah dikenal sekitar tahun 4000 SM. Keadaan alam merupakan salah satu syarat majunya kebudayaan Mesir. Sungai Nil merupakan sungai terpanjang di dunia yaitu mencapai $6400 \mathrm{~km}$, mengalir dari arah selatan ke utara dan bermuara ke laut Tengah dan melewati empat Negara, yaitu Uganda, Sudan, Ethiopia dan Mesir.

Sungai Nil meninggalkan lumpur subur dengan tanaman-tanaman yang tumbuh di sekitar sungai Nil diantaranya gandum dan kapas. Faktor geografis, mampu membuat bangsa Mesir menerapkan keseimbangan alam dengan tata cara pembagian air sungai Nil yang tetap dilestarikan. Sehingga mereka dapat mengenal alam. Faktor geografis yaitu hidup di sekitar lembah menuntut mereka untuk hidup keras karena sering terjangkit penyakit seperti malaria dan parasit schistosomiasis yang dapat mengakibatkan kerusakan hati dan pencernaan.

Untuk itu muncullah ilmu dan alatalat pengobatan Mesir kuno pertama kali.
Akhirnya kondisi geografis mendukung masyarakat Mesir menempati sekitar lembah sungai Nil hidup secara menetap dan mampu mengembangkan kebudayaannya. Di akhir abad XX potensi geografi menjadi peluang bagi Barat khususnya Inggris untuk membentuk imperium salah satunya di tanah Mesir. Berikut ini merupakan penggunaan media komik untuk menganalisis potensi geografis Timur Tengah salah satunya Mesir, dengan PPR oleh Prihatin Triwahyuniningsih:
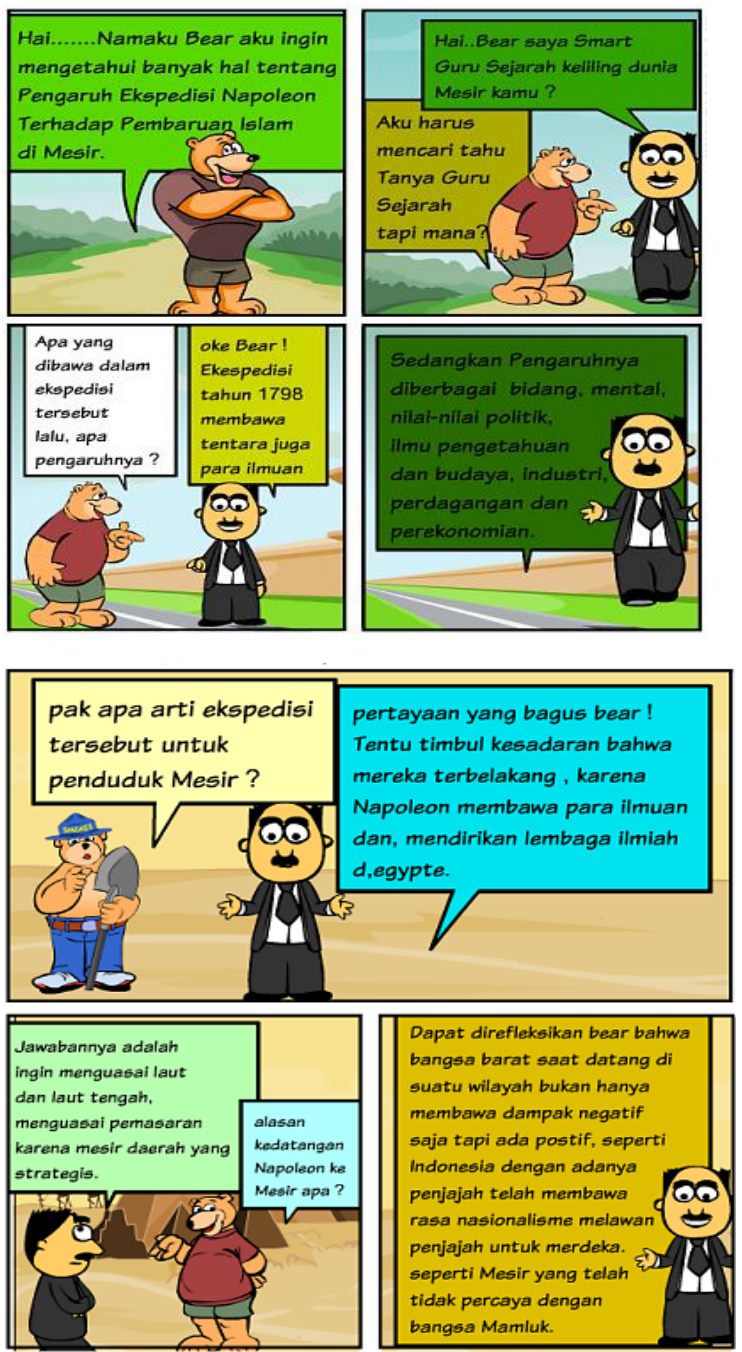

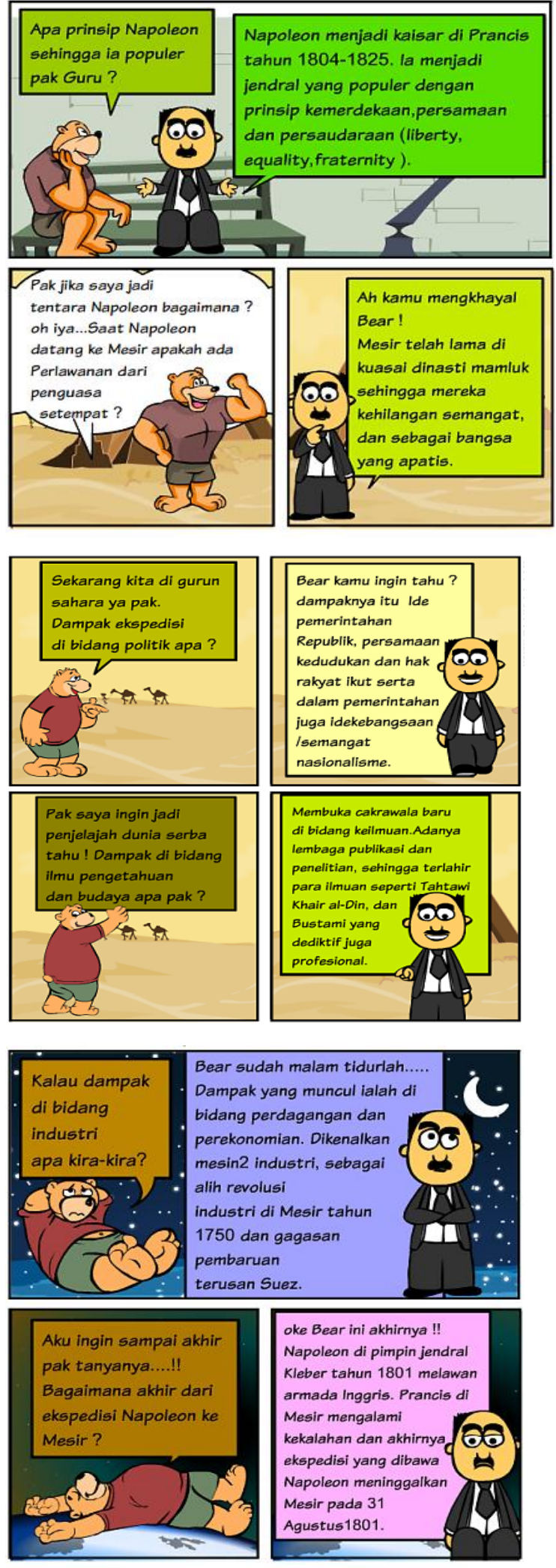

Gambar 1. Komik Tondoo Peradaban Mesir

\section{B. Potensi Geografis Bekas Peradaban Mesopotamia}

Mesopotamia berasal dari dua kata bahasa Yunani yaitu mesos berarti tengah dan potomos berarti sungai. Mesopotamia berarti daerah yang terletak di antara dua sungai besar yaitu sungai Eufrat dan Tigris. Wilayah ini dikenal dengan sebutan bulan sabit, sebab daerahnya menyerupai bulan sabit. Wilayah di tepi sungai Eufrat dan Tigris merupakan wilayah subur sehingga dapat mendatangkan manfaat bagi kehidupan masyarakan di wilayah tersebut (Sigihardjo Simobroto Budiawan, 1989: 34).

Di abad ke XX wilayah ini menjadi wilayah yang berpotensi namun juga menimbulkan konflik. Kekecewaan Saddam terhadap negara GCC yang telah dilindunginya dari ancaman revolusi Islam Iran. Pada saat perang Teluk 1, posisi Saddam dan GCC ibarat tukang pukul dan para cukongnya. Namun pada saat Irak babak belur akibat perang selama 8 tahun dengan Iran, negara GCC, khususnya Kuwait dan Uni Emirate Arab, justru berupaya menusuk dari belakang dengan cara melanggar kuota produksi OPEC yang mengakibatkan anjloknya harga minyak di pasaran Internasional, yang tentunya akan memperparah kondisi ekonomi Baghdad.

Akibat pelanggaran kuota OPEC yang dilakukan Kuwait dan Uni Emirates Arab, harga minyak sempat anjlok sampai sekitar 15 dolar AS perbarel. Irak yang mengandalkan minyak sebagai komoditi utama sangat terpukul dengan anjloknya harga minyak di pasaran Internasional. 
Apalagi pendapatan dari sektor minyak sangat dibutuhkan Irak untuk merekonstruksi kembali kerusakan akibat perang dengan Iran selama Perang Teluk.

Selain karena krisis minyak Irak, juga melancarkan serangan karena faktor historis politis. Kuwait adalah wilayah Irak (dulu Mesopotamia) sehingga sampai 1990 Irak secara konstitusional tidak mengakui Negara Kuwait. Ketika Kuwait memproklamasikan diri tahun 1961, Irak tidak mengikutinya. Dengan demikian, posisi Kuwait tetap menjadi wilayah kekuasaan Irak atau adanya ketidakjelasan perbatasan antara negara Kuwait dan Irak sehingga seringkali Irak mengklaim bahwa itu adalah daerahnya.

Berikut merupakan penggunaan media komik untuk menganalisis Potensi Geografis Bekas Peradaban Mesopotamia salah satunya Perang Teluk II (Irak-Kuwait), dengan PPR oleh Anastasia Lefiana Dewi:
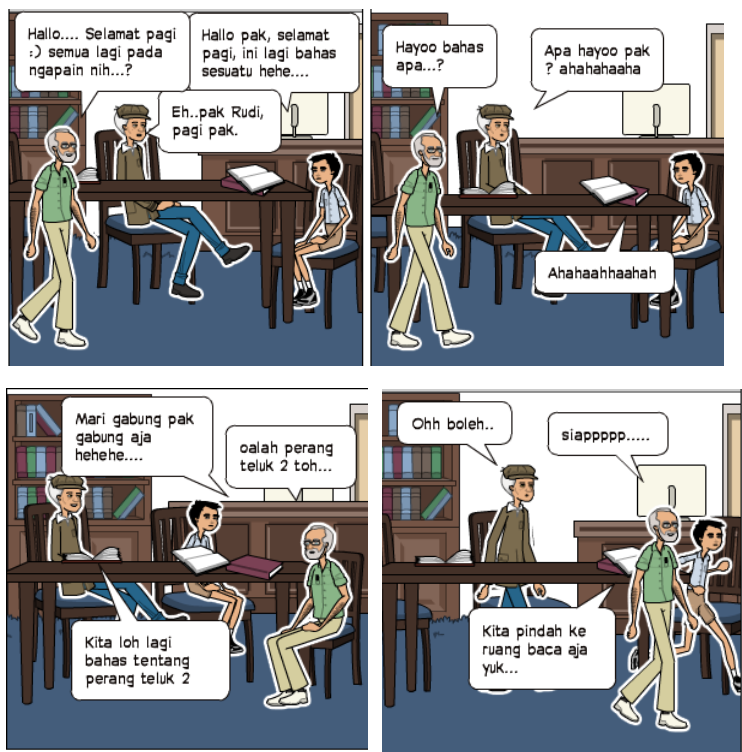
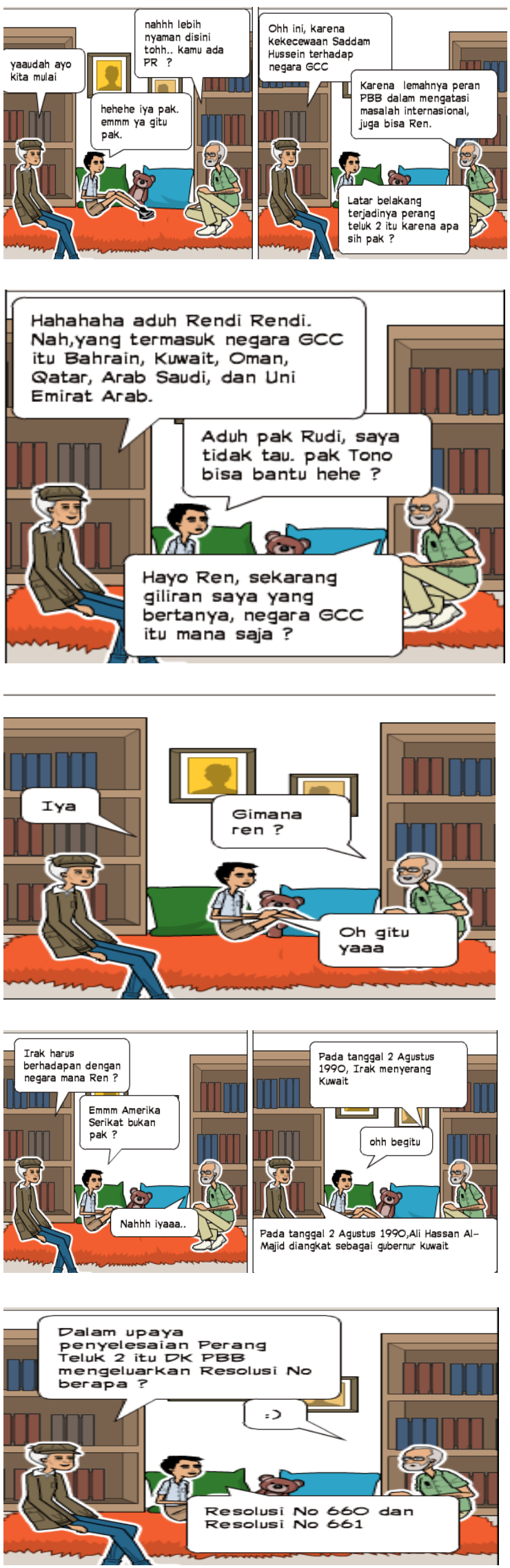

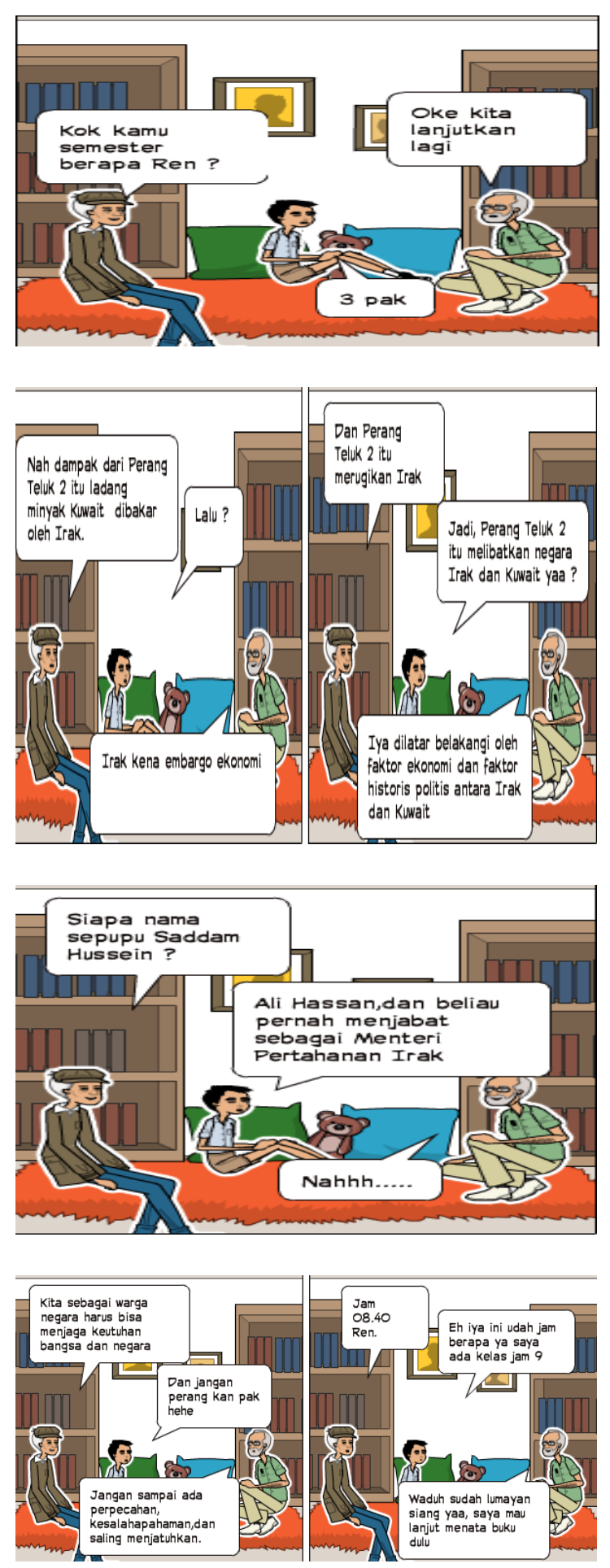
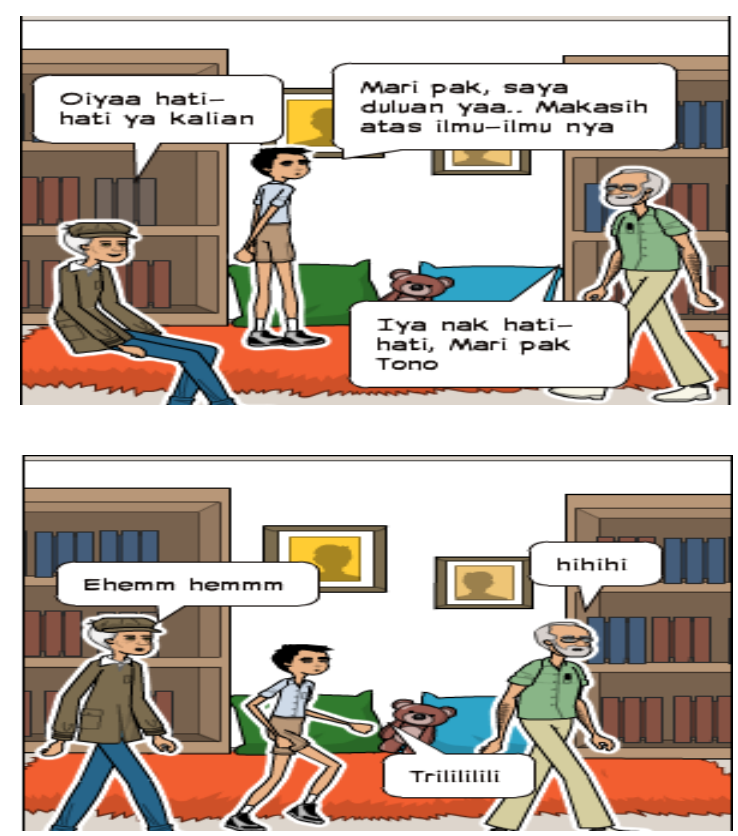

Gambar 2. Komik Tondoo Pedadaban Mesopotamia

\section{Potensi Geografis Bekas Peradaban \\ Persia}

Peradaban Persia terdiri atas sejumlah bangsa yang berkuasa di Dataran Tinggi Iran diantaranya Persia, Asia Barat, Asia Tengah dan Kaukasus. Berikut merupakan kronologi kebangkitan peradaban Persia di bawah sejumlah kekaisaran. Diantaranya kekaisaran Media dan Akhemeni yang berdiri pada tahun 728SM-550SM berdiri kekaisaran pertama Iran yang dihuni oleh bangsa Arya. Saat kerajaan Persia di bawah pemerintahan Darius ibu kota Persia dipindahkan dan mulai membangun Persepolis (sebuah terusan di antara Sungai Nil dan Laut Merah) dan menjandikannya pelopor untuk pembangunan Terusan Suez (Sigihardjo Simobroto Budiawan, 1989: 34). 
Pertikaian antara Irak dan Iran bukan soal baru. Sejak lama kedua negara tetangga itu bermusuhan karena berbagai hal. Pertama, antara bangsa Arab dan bangsa Parsi selalu ada persaingan. Yang satu tidak dapat menerima keunggulan atau dominasi yang lain. faktor yang kedua adalah masalah minoritas etnis. Pada zaman Shah Iran mendukung perjuangan otonomi suku kurdi di Irak, sedangkan Irak mendukung minoritas Arab di Iran yang memperjuangkan kebebasan yang lebih besar atau bahkan pemisahan.

Ketegangan Irak-Iran itu mereda berkat Perjanjian Aljazair tahun 1975. Berdasarkan penjanjian itu, maka Iran akan mengehentikan dukungan yang sejauh itu diberikan kepada pemberontakan suku Kurdi dan Perbatasan Irak-Iran di Shatt AlArab digeser dari tepi ke tengah perairan. Irak sebenarnya kurang setuju dengan penetapan perbatasan itu, tetapi tidak dapat menolaknya karena pada waktu itu Iran merupakan kekuatan dominan di kawasan dan Irak menghadapi pemberontakanpemberontakan suku Kurdi yang didukung oleh Teheran (Dilip Hiro, 1991: 60).

Berikut ini merupakan penggunaan media komik untuk menganalisis potensi geografis bekas peradaban Persia salah satunya Perang Teluk II (Irak-Kuwait), dengan PPR oleh Anastasia Lefiana Dewi:
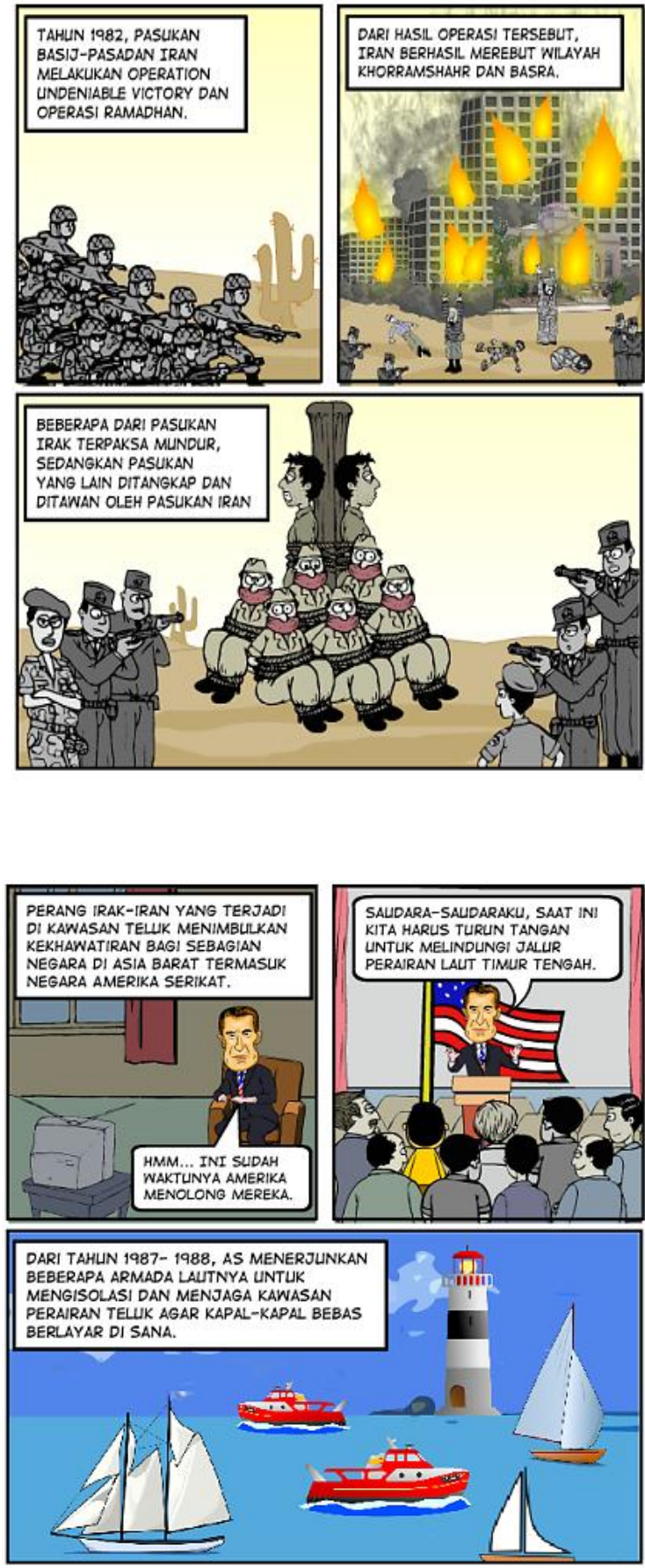


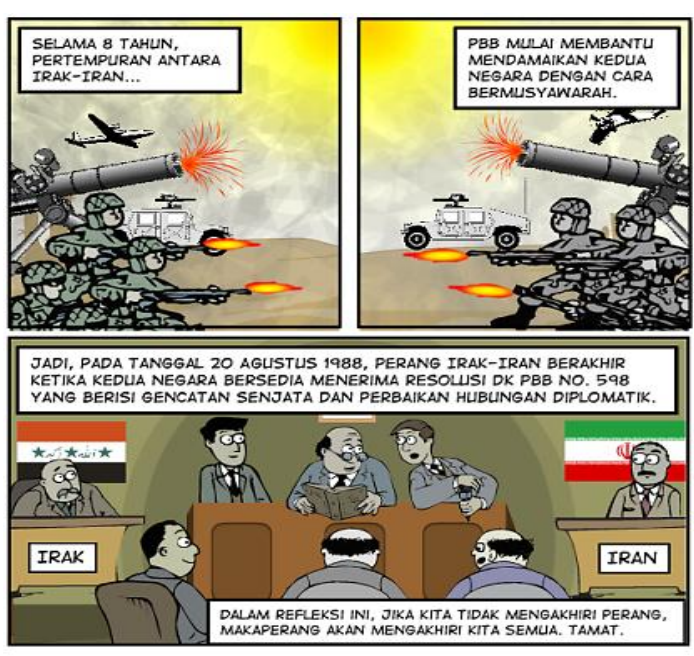

Gambar 3. Komik Tondoo Peradaban Persia

Upaya mengembangkan potensi geografis Timur Tengah menjadi kekuatan teritori. Banyak pelopor nasionalisme Arab yang memiliki misi menyelamatkan bangsanya terbebas dari tradisi yang terlalu konservatif untuk tetap memajukan bangsa serta terbebas dari penetrasi asing diantaranya Sultan Abdul Hamid II (Turki), Al-Tahtawi (Mesir), Muhammad Rashid Rida (Syria), Mustafa Kemal Ataturkh (Turki), Gammal Abdul Nasser (Mesir).

Selain gagasan para nasionalis wilayah lain yang merasakan pengaruh asing yang kuat langsung bereaksi dengan membuat ketetapan netralitas dengan tidak memihak blok manapun yang memiliki kepentingan. Namun, ada pengecualian untuk Arab Saudi dimana AS tetap bekerjasama dalam bidang ekonomi dan terbukti dengan adanya perusahaan asing ARAMCO (Arabia American Company Oil). Ini dirasa lebih menguntungkan dari pada menempatkan pangkalan militer asing. Hasil penelitian menunjukkan analisa potensi geografis Timur Tengah merupakan bagian penggalian konsep. Penggalian aksi dan refleksi telah disampaikan bersamaan dengan media komik digital. Semua adalah rangkaian pelaksanaan pembelajaran berlandaskan paradigma pedagogi reflektif.

Hal ini senada dengan gagasan Paul Suparno (2015: 10), paradigma pedagogi reflektif adalah suatu pedagogi bukan hanya sekedar metode pembelajaran, tetapi suatu pendekatan serta cara pengajar mendampingi peserta didik sehingga menjadi pribadi yang utuh (Paul Suparno, 2015: 18).

Frekuensi penugasan komik menunjukkan sebagian mahasiswa memilih materi mengenai analisa potensi geografis Timur Tengah. Hal tersebut seperti ditunjukkan dalam diagram berikut ini:

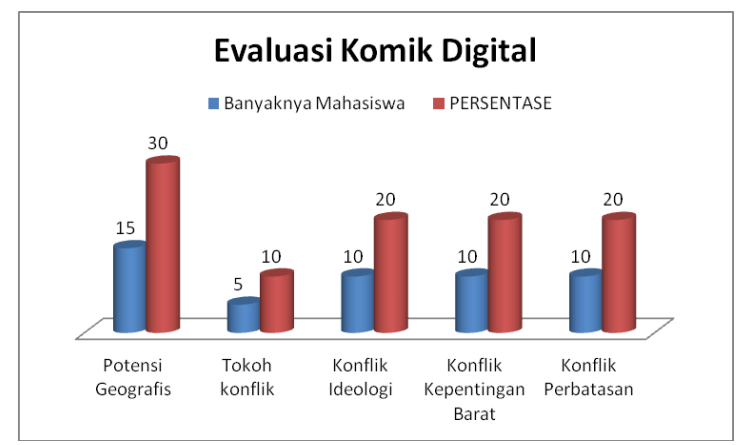

Diagram 1. Frekuensi komik digital dengan topik terbanyak potensi geografis Timur Tengah

Dari diagaram dapat digambarkan bahwa mahasiswa yang memilih topik Potensi Geografis Timur Tengah sebesar $30 \%$ atau sekitar 15 dari jumlah keseleuruhan mahasiswa 50, sedangkan topik lain (tokoh, konflik ideologi, konflik 
kepentingan barat, konflik perbatasan) mendapatkan porsi rata-rata seitar 10-20\%.

\section{Penutup}

Analisa potensi geografis Timur Tengah menjadi kekuatan teritori melalui komik digital berlandaskan paradigma pedagogi reflektif menjadi salah satu sarana yang tepat untuk pendidikan sejarah dalam menanggapi era Revolusi Industri 4.0. Banyak pelopor nasionalisme Arab yang memiliki misi menyelamatkan bangsanya terbebas dari tradisi yang terlalu konservatif untuk tetap memajukan bangsa serta terbebas dari penetrasi asing diantaranya Sultan Abdul Hamid II (Turki), Al-Tahtawi (Mesir), Muhammad Rashid Rida (Syria), Mustafa Kemal Ataturkh (Turki), Gammal Abdul Nasser (Mesir).

Selain gagasan para nasionalis, wilayah lain yang merasakan pengaruh asing yang kuat langsung bereaksi dengan membuat ketetapan netralitas dengan tidak memihak blok manapun yang memiliki kepentingan. Namun, ada pengecualian untuk Arab Saudi dimana AS tetap bekerjasama dalam bidang ekonomi dan terbukti dengan adanya perusahaan asing ARAMCO (Arabia American Company Oil) dan ini dirasa lebih menguntukan dari pada menempatkan pangkalan militer asing.

Adapun hasil mahasiswa yang memilih topik Potensi Geografis Timur Tengah sebesar $30 \%$ atau sekitar 15 dari jumlah keseleuruhan mahasiswa 50, sedangkan topik lain (tokoh, konflik ideologi, konflik kepentingan barat, konflik perbatasan) mendapatkan porsi rata-rata seitar $10-20 \%$.

Pada akhirnya diharapan setiap elemen pendidikan khususnya pendidik sejarah mampu bertransformasi dan tanggap zaman sehingga selalu dimudahkan baik dalam proses maupun dalam pengelolaan pembelajaran.

\section{Daftar Pustaka}

Bixby, Asgar. 1992. Timur Tengah di Tengah Kancah Dunia. Bandung:Sinar Baru Algensindo.

Budiawan, Sigihardjo Simobroto. 1989. Sejarah Peradaban Barat Klasik dari Pra Sejarah Hingga Runtuhnya Romawi. Yogyakarta: Liberty.

Dipoyudo, Kirdi. 1981. Timur Tengah Pusaran Strategis Dunia. Jakarta: Yayasan Proklamasi CSIS.

Hiro, Dilip. 1991. The Longest War: The Iran-Irak Military Conflict. New York: Routledge.

R.H. Davison, "Where is the Middle East," dalam Richard H.Nolte, The Modern Middle East.New York. 1963., hlm.1329; dan karangan "The Middle East," dalam Encyclopedia Americana. New York, 1971. Jilid 19.hlm.38-381

Suparno, Paul. 2015. Paradigma Pedagogi Refleksi (PPR). Universitas Sanata Dharma.

www.toondoo.com 